\title{
Aikuiskasvatuksen tutkijat kevytyhteisön ajassa
}

A ikuiskasvatuksen tutkijatapaaminen pidettiin Lapin yliopistossa 14. - 15. helmikuuta. Tapaamisen järjestivät Aikuiskasvatuksen Tutkimusseura ry (ATS) sekä Lapin yliopiston kasvatustieteiden tiedekunta. Kahdeksatta kertaa kokoontuneen tutkijatapaamisen teemana oli "Aikuiskasvatus kevytyhteisöjen ajassa”. Kevytyhteisön käsitteen avulla haluttiin virittää keskustelua yhteisön ja yhteisöllisyyden merkityksestä. Päivien aikana teemasta käytiin keskustelua muun muassa sukupuolen, kansalaisuuden, koulutuksen ja työelämän näkökulmista. Tapaaminen houkutteli paikalle toistasataa osallistujaa aikuiskasvatuksen eri kentiltä. Aikuiskasvatuksen opiskelijana osallistuin itse tutkijatapaamiseen suorittamalla opintoihin kuuluvan työharjoitteluni ryhmässä, joka suunnitteli ja toteutti tilaisuuden.

Päivät avasi Lapin yliopiston tutkijakoulun johtaja professori Suvi Ronkainen tarkastelemalla kevytyhteisön ajatusta. Kaksipäiväinen tapaamisen ohjelmassa oli kolme pääluentoa sekä 10 eri teemaryhmää. Teemaryhmissä oli yhteensä kaiken kaikkiaan 63 esitystä. Teemaryhmät päivien aikana olivat seuraavat: vapaa sivistystyö, sukupuolen merkitys aikuiskasvatuksen yhteisöissä, ammattikorkeakoulut aikuisten osaamisen ja alueellisen ammattiosaamisen vahvistajina, aikuisopiskelijat avoimissa korkeakouluyhteisöissä, aikuiset, ohjaus ja yhteisöt, oppimisyhteisöt työssä ja koulutuksessa, aktiivinen kansalaisuus, kansalaistoiminta, työyhteisö syrjijänä, hyvinvointi ja elämänhallinta aikuisuudessa ja yrittäjyyskasvatus. Teemaryhmissä tutkijat esittelivät omia meneillään olevia tutkimuksiaan tai projektejaan. Ryhmien määrä ja monipuolisuus kuvastaa aikuiskasvatuksen kentän laajuutta.

Pääluennoitsijat päivillä olivat dosentti Leena Kurki Tampereen yliopistosta, tutkija Barbara Merrill Warwickin yliopistosta ja professori Anneli Eteläpelto Jyväskylän yliopistosta. Luentoja kommentoivat professorit Kari. E. Nurmi, Päivi Naskali ja Esa Poikela Lapin yliopistosta.

Leena Kurjen aiheena oli yhteisöllisyys kansalaisuuden voimavarana. Kurjen mukaan yhteisökäsitteen pohtiminen ei riitä, kun keskustellaan yhteisöllisyydestä ja yhteiskunnallisista asioista, vaan tulee olla näkemys ihmisestä, persoonasta. Hän käsitteli yksilön persoonaa Martin Buberin esittämän Minä-Sinä ja Minä-Se -sanaparien kautta. Sanaparit kertovat ihmisten välisistä suhteista. Kurki painotti, että ihmiset ovat myös dynaamisia toimijoita, jotka toimivat yhteisesti kulttuuriinsa sitoutuen. Toiminnassa ihminen rakentaa itseään, mutta myös toimii yhdessä toisten ihmisten kanssa. Kulttuuri on toimivien ihmisten erityistä, persoonallista ja yhteisöllistä "kohtalon luomista”, johon pitää kasvaa. Tätä kasvua voidaan tukea sosiokulttuurisella innostamisella sekä vapautuksen pedagogiikan menetelmillä. Hän tiivisti ajatuksensa sanoin: "Persoonallisen ja sosiaalisen, yhteisöllisen, kehittymisen välinen suhde on niin tiivis, että aitoa yhteisöä ei yksinkertaisesti ole mahdollista rakentaa ilman persoonallisen kehittymisen onnistumista."

Luennossa "Gender, Class and Society" Barbara Merrill toi yhteisöllisyyskeskusteluun brittiläisen näkökulman. Hän tarkasteli työväenluokkaisesta taustasta tulevien naisten ja miesten identiteettien muotoutumista korkeakouluopintojen aikana. Vaikka yliopisto tuntui heille vieraalta paikalta, hyvä opiskelijayhteisö oli avuksi opinnoissa. Opiskelijat pohtivat muuttuneita identiteettejään sukupuolen, luokan ja etnisyyden näkökulmista.

Anneli Eteläpelto tarkasteli esityksessään ammatillisia identiteettejä työelämän ja koulutuksen yhteydessä: minkälaisia haasteita, rajoitteita ja ongelmia ammatillisten identiteettien rakentumisessa syntyy? Eteläpellon mukaan identiteettityö on koko työuran jatkuva keskeinen tehtävä. Oppiminen ja identiteettien rakentuminen tapahtuu yksilön ja yhteisön vastavuoroisessa suhteessa. Yhteisön tulee antaa yksilölle mahdollisuudet vaikuttaa yhteisössään, pelkkä jäsenyys tai yhteisöön kuuluminen ei riitä. Työn pitää olla myös merkityksellistä ja mielekästä, jotta se sitouttaa positiivisesti ihmisen työhönsä. Resurssien puute, liian suuri työkuorma ja kiire heikentävät työssä oppimista ja identiteettien yhteisöllistä neuvottelua. Työssä jaksamista ja oppimista edesauttaa toimi- 
va ja tukeva lähiyhteisö, jossa vallitsee hyvä ilmapiiri. Esimerkiksi stressitutkimukset osoittavat, että liian suuri työmäärä, jatkuva kiire, vähäiset vaikutusmahdollisuudet ja huono työilmapiiri ovat ihmisten hyvinvoinnin ja terveyden kannalta vaarallisia.

Aikuiskasvatuksen tutkijatapaamisen iltajuhlaa vieraat pääsivät juhlimaan Lapin yliopiston uusimmissa tiloissa ravintola Petronellassa. Illanvieton avasi puheellaan kasvatustieteiden tiedekunnan dekaani Kaarina Määttä. Illanvietto sisälsi tarjoilun lisäksi lappilaista musiikkia haitarinsoittaja Pertti Vaattovaaran tahdittamana. Illanvieton kruunasi Esa ja Sari Poikelan julkistama professori Kari. E. Nurmen juhlakirja "Tutkimustarinoita Ounaksen varrelta”. Tutkijatapaamisen lopetussanat lausui Aikuiskasvatuksen Tutkimusseuran puheenjohtaja Anja Heikkinen.
Koin tutkijatapaamisen virkistävänä, avartavana ja opettavaisena kokemuksena. Pääasiassa olin mukana suunnittelussa ja toteutuksessa ja esimerkiksi päivien aikana teemaryhmiin en ennättänyt osallistua. Luentojen aiheet olivat mielenkiintoiset ja itseäni alkoi kiinnostaa erityisesti Leena Kurjen aihe, joka liittyi persoonaan ja yhteisöön. Suurin anti itselleni oli kuitenkin itse suunnitteluja toteutusryhmään kuuluminen ja siinä toimiminen. Teemaryhmiin tutustuin abstrakteja lukemalla ja tämän myötä huomasin, kuinka laaja aikuiskasvatuksen kenttä on. Tästä huomiosta on apua omissa opinnoissani.

Suosittelen kaikkia opiskelijoita osallistumaan tutkijatapaamisiin tulevaisuudessa. Seuraava aikuiskasvatuksen tutkijatapaaminen pidetään 2010 Joensuussa. 